\title{
First report of Neofusicoccum parvum causing branch dieback on Juglans regia in Turkey
}

\author{
Merve Kara $^{1} \cdot$ Emine Mine Soylu $^{1} \cdot$ Soner Soylu $^{1} \cdot$ Aysun Uysal $^{2} \cdot$ Şener Kurt $^{1}$ \\ Received: 6 April 2020 / Accepted: 10 September 2020 / Published online: 13 September 2020 \\ (C) Società Italiana di Patologia Vegetale (S.I.Pa.V.) 2020
}

Keywords Neofusicoccum parvum $\cdot$ Walnut $\cdot$ Dieback $\cdot$ Juglans regia

During June 2019, dieback symptoms and cankers were observed on branches of English walnut (Juglans regia L.) trees growing in Hatay provinces of Turkey. Isolations were made from surface disinfected diseased branches and cankers tissues on potato dextrose agar (PDA). Colonies of the fungal isolate were initially pale to white with but diffused yellow pigment into PDA seven days later. Single-conidial cultures were induced to sporulate on $2 \%$ water agar bearing double-autoclaved pine needles. Brown, globular conidiomata were 250 to $525 \mu \mathrm{m}$ in diameter. Hyaline, aseptate rod shaped conidia were 3.5-5.5 $\times 1.5-2.5 \mu \mathrm{m}$. Hyaline, 1-2 septate macroconidia were $16.0-19.5 \times 4.5$ $6.0 \mu \mathrm{m}$. The morphological characteristics closely resembled those described for Neofusicoccum parvum (Pennycook \& Samuels) Crous, Slippers \& A.J.L. Phillips (Slippers et al. 2004). The internal transcribed spacer (ITS) and $\beta$-tubulin gene (TUB) regions were amplified from DNA of the representative isolate WNp31 with primers ITS4/ITS5 and $\mathrm{Bt} 2 \mathrm{a} / \mathrm{Bt} 2 \mathrm{~b}$ (Glass and Donaldson 1995). The consensus sequences of ITS (GenBank accession N. MT012295) and TUB (MT015600) genes showed $99.8-100 \%$ identity with sequences of N. parvum (MH623075, KF778959). Pathogenicity test was performed on branches of 2-year-old walnut sapling (cv. Chandler) by inoculating mycelial plugs into bark wounds on branches of sapling kept in a growth room at $25^{\circ} \mathrm{C}$. Controls were inoculated with sterile PDA plugs. Typical necrotic lesions were observed at the inoculation sites of inoculated branches three weeks after inoculation. No lesions were observed on the control branches. $N$. parvum was re-isolated from inoculated branches and

Soner Soylu

soylu@mku.edu.tr

1 Department of Plant Protection, Hatay Mustafa Kemal University, Faculty of Agriculture, Hatay 31034, Turkey

2 Centre for Implementation and Research of Plant Health Clinic, Hatay Mustafa Kemal University, Hatay 31034, Turkey identified as described above. Based on morphological characteristics and phylogenetic analyses of the sequences of ITS and TUB gene regions, Neofusicoccum parvum was identified. This disease agent has been reported on walnut trees in Iran, Spain, USA and China (Farr and Rossman 2020). To best of our knowledge, this is the first report of $N$. parvum infecting walnut in Turkey.

\section{Compliance with ethical standards}

Conflict of interest The authors declares that there is no conflict of interest for this submission.

Research involving human participants and/or animals This article does not contain any studies with human participants or animals performed by any of the authors.

Informed consent This manuscript is new and not being considered elsewhere. The authors have read and approved the submission of this manuscript.

\section{References}

Farr DF, Rossman AY (2020) Fungal Databases, U.S. National Fungus Collections, ARS, USDA. Retrieved May 22, 2020

Glass NL, Donaldson GC (1995) Development of primer sets designed for use with the PCR to amplify conserved genes from filamentous ascomycetes. Appl Environ Microbiol 61:1323-1330

Slippers B, Crous PW, Denman S, Coutinho TA, Wingfield BD, Wingfield MJ (2004) Combined multiple gene genealogies and phenotypic characters differentiate several species previously identified as Botryosphaeria dothidea. Mycologia 96:83-101 